\title{
Knowledge spillovers and wage inequality: An empirical analysis of Dutch manufacturing
}

Citation for published version (APA):

Bruinshoofd, W. A., Hollanders, H. J. G. M., \& ter Weel, B. J. (2001). Knowledge spillovers and wage inequality: An empirical analysis of Dutch manufacturing. Labour - Review of Labour Economics and Industrial Relations, 15(4), 641-661. https://doi.org/10.1111/1467-9914.00181

Document status and date:

Published: 01/01/2001

DOI:

10.1111/1467-9914.00181

Document Version:

Publisher's PDF, also known as Version of record

\section{Please check the document version of this publication:}

- A submitted manuscript is the version of the article upon submission and before peer-review. There can be important differences between the submitted version and the official published version of record.

People interested in the research are advised to contact the author for the final version of the publication, or visit the DOI to the publisher's website.

- The final author version and the galley proof are versions of the publication after peer review.

- The final published version features the final layout of the paper including the volume, issue and page numbers.

Link to publication

\footnotetext{
General rights rights.

- You may freely distribute the URL identifying the publication in the public portal. please follow below link for the End User Agreement:

www.umlib.nl/taverne-license

Take down policy

If you believe that this document breaches copyright please contact us at:

repository@maastrichtuniversity.nl

providing details and we will investigate your claim.
}

Copyright and moral rights for the publications made accessible in the public portal are retained by the authors and/or other copyright owners and it is a condition of accessing publications that users recognise and abide by the legal requirements associated with these

- Users may download and print one copy of any publication from the public portal for the purpose of private study or research.

- You may not further distribute the material or use it for any profit-making activity or commercial gain

If the publication is distributed under the terms of Article $25 \mathrm{fa}$ of the Dutch Copyright Act, indicated by the "Taverne" license above, 


\title{
Knowledge Spillovers and Wage Inequality: An Empirical Analysis of Dutch Manufacturing
}

\section{Allard Bruinshoofd - Hugo Hollanders - Bas ter Weel}

\begin{abstract}
The introduction of new technologies and technical change is associated mainly with high-skilled and high-wage workers. In addition, many studies have found a positive correlation between the introduction of new technologies and technical change and skill upgrading. In these studies no attention has been paid to spillovers from one sector to the other. In this paper we not only use measures of technical change but also knowledge spillovers to explain wage inequality in Dutch manufacturing in the period 1986-95. Using this more elaborate measure of technical change, our findings are twofold. First, we confirm that workers employed in knowledge-intensive manufacturing sectors receive a higher wage than workers in less knowledge-intensive sectors. Secondly, the wages paid to high-skilled workers relative to low-skilled workers in knowledge-intensive sectors are higher than those in less knowledge-intensive sectors. However, the coefficients using the elaborate measure of technological advancement are much lower and sometimes even insignificant. This suggests a premium for high-skilled labour in sectors both applying and developing technology. But the wage premium is highest in technology-developing sectors, as suggested by the measures used in previous studies.
\end{abstract}

\section{Introduction}

It is increasingly recognized that knowledge, both as an input in the production process and as a final product, is central to the

Allard Bruinshoofd, Department of Economics, Maastricht University, The Netherlands.

Hugo Hollanders, Maastricht Economic Research Institute on Innovation and Technology (MERIT), Maastricht University, The Netherlands.

Bas ter Weel (author for correspondence): MERIT, Maastricht University, P.O. Box 616, 6200 MD, The Netherlands. Tel: +31-43-3883873; e-mail: b.terweel@merit.unimaas.nl.

We would like to thank Andries de Grip, Luc Soete and an anonymous referee for helpful comments on an earlier draft of this paper. Ter Weel also acknowledges support from the Netherlands Organisation for Scientific Research (NWO). 
contemporary process of economic growth and wealth accumulation. Whereas the embodiment of knowledge in physical capital has long been acknowledged, the increasing importance of knowledge embodied in organizations and people has been acknowledged much more recently. Yet there is little doubt that the way to apply and use particular knowledge is an integral part of that specific piece of knowledge: human skills are essential and important complementary assets to implement, maintain, adapt to and use new physically embodied knowledge and technologies. From this perspective, as noted recently by Acemoglu (1998) and Goldin and Katz (1998), and initiated by an early contribution of Griliches (1969), human capital and knowledge are two faces of the same coin, two non-separable aspects of wealth accumulation.

This idea is closely related to the debate on skill-biased technical change and (wage) inequality: ${ }^{1}$ a higher proportion of skilled workers in the labour force implies a larger market for technology used by these workers. Therefore, an increased supply of these workers induces the development of technologies complementary to relatively skilled workers and to the employment of these skilled workers despite their rising relative wages. In the micro-econometric literature, a great deal of evidence has been brought together highlighting the reduction of the demand for unskilled labour relative to the demand for skilled labour. This skill bias can be explained by various factors. ${ }^{2}$ For instance, in Griliches (1969) it is due to the relative decline of the price of capital, while Denny and Fuss (1983) attribute the skill bias to the specific effects of technical change; Goldin and Katz (1998) conclude that new technologies are relatively complementary to more educated labour. In general, the rationale for the argument put forward is that skilled workers and advanced capital equipment seem to complement one another, whereas skilled and unskilled labour seem to be substitutes.

The aim of this paper is to investigate wages in Dutch manufacturing both on the basis of job types - white-collar versus blue-collar — and job levels - skilled versus unskilled. First, we determine the knowledge intensity of the manufacturing sectors by carrying out a spillover analysis. A number of OECD data sources on research and development $(R \& D)$ and patents are explored to determine knowledge intensity. The purpose of this analysis is to show how knowledge is created in a particular sector and applied and used in others. This provides a picture of both the 
knowledge flows within the Dutch manufacturing sector and the degree to which imported knowledge affects the production process. Most of the literature analysing the structure of wages does not consider spillovers when discussing the positive correlation between skilled workers' wages, skill upgrading and technical change. ${ }^{3}$ Once we have determined which sectors are relatively knowledge intensive, we look at the wage levels in these sectors starting from the two following questions. First, do knowledgeintensive sectors pay a higher wage to their workers than less knowledge-intensive sectors? Secondly, do knowledge-intensive sectors pay a higher wage to high-skilled workers relative to lowskilled workers than less knowledge-intensive sectors? Our findings can be summarized as follows. From a simple analysis of using the OECD's classification of technological advancement, we find a positive correlation between a sector's technological advancement and the level of wages. It also turns out that higher-skilled and white-collar workers earn higher wages in technologically advanced sectors. When including the different measures of knowledge into this empirical analysis, we observe that the wage premiums are much lower and in some instances even insignificant. This suggests that only taking into account the development of new technologies without analysing its applications is probably not a consistent way to analyse the data. Including knowledge spillovers leads to a picture that not only analyses the development of technology but also the use of technology in other sectors. Apparently, the use of advanced technologies goes hand in hand with less high wage premiums for higher-skilled workers than the development of these technologies. This means that the estimated wage premiums of previous studies have neglected some counterbalancing effect of technical change, which has led to some overestimation of the effect of technical change when including knowledge spillovers to other sectors. It also suggests that the assumed complementary relationship between capital and higherskilled workers is likely to be stronger when the development of new technologies is considered as opposed to the use of these new technologies.

The plan of the remainder of this paper is as follows. In Section 2 we put forward the spillover analysis and discuss the importance of taking into account knowledge spillovers. Section 3 addresses the impact of knowledge intensity on wages and wage differentials between different types and levels of workers. Section 4 concludes. 


\section{Knowledge spillovers}

Several studies have demonstrated that R\&D and its spillovers play a significant role in explaining economic growth. ${ }^{4}$ For example, Coe and Helpman (1995) studied international R\&D spillovers in a long-run equilibrium model and concluded that R\&D spillovers play a prominent role in explaining productivity growth and productivity convergence across countries. ${ }^{5}$ Verspagen (1997) investigated the impact of international knowledge spillovers on sectoral growth patterns in OECD countries. Using a technology flow matrix to determine the extent of the spillovers, it is concluded that international knowledge spillovers are an important contributor to economic growth.

\subsection{Framework}

This section explores the importance of the impact of sectoral knowledge spillovers on labour productivity in Dutch manufacturing in the period 1986-95. We make use of the following simple Cobb-Douglas production function

$$
Y_{j, t}=A_{j} K_{j, t}^{\alpha} L_{j, t}^{\beta} C_{j, t}^{\rho} I C D_{j, t}^{\delta} I C W w_{j, t}^{\phi},
$$

where subscript $j$ refers to sector $j$ and $t$ is a time index. The data used relate to the manufacturing sector and have been extracted from the OECD's STAN, ANBERD and BITRA databases. ${ }^{6} Y$ is defined as value added generated in the production process, $A$ is a scale variable, $K$ is the capital stock, $L$ the amount of labour used in the production process, $C$ the knowledge created and applied in sector $j$ by means of $\mathrm{R} \& \mathrm{D}, I C D$ is the Dutch publicly available knowledge, and $I C W$ is the worldwide publicly available knowledge, i.e. indirect knowledge spillovers from abroad. The parameters $\alpha, \beta, \rho, \delta, \phi$ are the elasticities with respect to each of them.

Using the perpetual inventory method, the physical capital and knowledge stock are constructed as

$$
K_{t}=(1-\varphi) K_{t-1}+I_{K, t}
$$

and

$$
C_{t}=(1-\chi) C_{t-1}+I_{C, t},
$$


where $\varphi$ and $\chi$ are the depreciation rates with respect to the physical capital and knowledge stock, respectively. $I_{K, t}$ and $I_{C, t}$ are defined as the (annual) investments in both stocks. For $K_{t}$ and $C_{t}$ a depreciation rate of 5 percent and 15 percent is assumed. ${ }^{7}$

The indirect knowledge stocks were constructed using a technology flow matrix (Verspagen, 1997). This matrix is constructed using data from the European Patent Office (EPO), which assigns each patented invention to a single 'main technology class' and one or several 'supplementary technology classes'. A concordance scheme between the technological classes and industries assigns both the main technology class and the supplementary technology class to an industry. The construction of the matrix we use here can be compared with the one known as the Yale-matrix constructed by Putnam and Evenson (1994) and applied by Kortum and Putnam (1997). However, the Yale-matrix is aimed at measuring rent spillovers, while the matrix we use is aimed at measuring knowledge spillovers. ${ }^{8}$ The major innovation of the knowledge spillover matrix is that besides rent spillovers generated by international trade, spillovers generated by blueprints, like patents, are also taken into account. Particularly in manufacturing, the use of blueprints is likely to be an important source of spillovers because it is well known that different sectors use (partially) similar technologies and modes of production.

The domestic indirect knowledge stock for sector $k$ is then defined as

$$
I C D_{k}=\sum_{j} \omega_{j k} C_{j}\left(1-m_{j}\right)
$$

and the foreign knowledge stock for the same sector is

$$
I C W_{k}=\sum_{W} \sum_{j} \omega_{j k} C_{W j} S_{W j} m_{j}
$$

where, $\omega_{j k}$ is the sector-specific part of R\&D performed by sector $j$ that spills over to sector $k$, and $m_{j}$ is the import share of sector $j .9$ The number of countries included in the set $W$ is limited to the most important OECD trading partners of The Netherlands (with the exception of Belgium owing to a lack of R\&D data): Australia, Canada, Denmark, Finland, France, Germany, Italy, Japan, Norway, Spain, Sweden, the UK and the USA. The variable 
labelled $S_{W j}$ represents the import share of Dutch sector $j$ from country $W$.

Now we rewrite equation [1] in logs to perform the estimations. We do this by dividing all variables, except $I C D$ and $I C W$ by $L$ and subsequently taking logarithms. This leads to equation [6] ${ }^{10}$ which is subject to further estimation:

$$
\begin{aligned}
y_{j, t}-l_{j, t}= & a+\alpha\left(k_{j, t}-l_{j, t}\right)+\lambda l_{j, t}+\rho\left(c_{j, t}-l_{j, t}\right) \\
& +\operatorname{\delta icd}_{j, t}+\phi i c w_{j, t} .
\end{aligned}
$$

\subsection{Estimation results}

The database constructed to estimate equation [6] is a panel database. To estimate equation [6] we make use of within regressions. This regression method used to estimate panel data is in essence an OLS regression in which the average value of the variable is subtracted from the variable's actual value for each sector. The main reason for using the within regression method is that it exploits the time series variability over time - in this case the period 1986-95. Table 1 displays the results of estimating various forms of equation [6].

The regression results reported in the first row of Table 1 show the estimation of equation [6] without taking into account

Table 1. The importance of knowledge spillovers for labour productivity in Dutch manufacturing, 1986-95 (dependent variable ln (value added))

\begin{tabular}{ccccc}
\hline $\begin{array}{c}\alpha \\
\boldsymbol{k}-\boldsymbol{l}\end{array}$ & $\begin{array}{c}\rho \\
\boldsymbol{c}-\boldsymbol{l}\end{array}$ & $\begin{array}{c}\delta \\
\boldsymbol{i c d}\end{array}$ & $\begin{array}{c}\phi \\
\boldsymbol{i c w}\end{array}$ & $\boldsymbol{R}^{2}$ adj. \\
\hline $0.379(0.033)^{*}$ & $0.102(0.023)^{*}$ & & & 0.425 \\
$0.199(0.045)^{*}$ & $0.106(0.022)^{*}$ & $0.210(0.037)^{*}$ & & 0.463 \\
$0.214(0.037)^{*}$ & $0.079(0.022)^{*}$ & & $0.165(0.020)^{*}$ & 0.496 \\
$0.140(0.044)^{*}$ & $0.085(0.022)^{*}$ & $0.117(0.038)^{*}$ & $0.139(0.022)^{*}$ & 0.505 \\
\hline
\end{tabular}

Notes: All regressions are estimated using within regressions. The data are taken from the OECD's STAN, ANBERD and BITRA databases. Standard errors are shown in parentheses.

*Significant at the 5 percent level.

$\lambda=\alpha+\beta+\rho-1$. Including the $\lambda$-term in these regressions results in statistically insignificant coefficients (the hypothesis of constant returns to scale is thus not rejected). 
domestic and international knowledge spillovers. The coefficient of the capital-labour ratio is 0.379 and the direct knowledge stock has a positive and significant effect on labour productivity: 0.102 . The second row reports the results of including domestic knowledge spillovers. The elasticity of the capital-labour ratio is now 0.199 , and the elasticity of the direct knowledge stock remains almost equal: 0.106 . The indirect domestic knowledge stock shows a large significant effect on labour productivity of 0.210 , which is consistent with the results reported by Coe and Helpman (1995) for other OECD countries. The elasticity of the domestic indirect knowledge stock is twice as large as the elasticity of the direct knowledge stock, which reflects the importance of what Soete and Ter Weel (1999) refer to as a 'public knowledge basin' for labour productivity. This result is interesting because it suggests that by taking into account only a sector's own investments, the use of knowledge by this sector is underestimated to quite a large extent. ${ }^{11}$

The third row of Table 1 reports the coefficients of including international knowledge spillovers into the regression equation. The results suggest that international knowledge spillovers also have a significant effect on labour productivity: 0.165 . The elasticity of the capital-labour ratio is comparable with that obtained when only domestic knowledge spillovers are included. However, the coefficient of the direct knowledge stock has decreased. The results from this third row suggest that the effect of international knowledge spillovers on labour productivity is twice as large as that of the sectors' own direct knowledge stock, which shows the importance of using knowledge developed by others. $^{12}$

Finally, the fourth row of Table 1 reports the regression results when we include both domestic and international knowledge spillovers. The results suggest that the elasticity of international spillovers is not only about 20 percent larger than that of domestic spillovers, it is also of the same size as the elasticity of the capital-labour ratio. This important role for spillovers in the manufacturing sector in The Netherlands is consistent with The Netherlands being referred to as an importing and exporting country: it suggests that spillovers from abroad play an important role in the performance of the sector and should therefore not be neglected when investigating the wage structure of the different sectors within manufacturing in relation to technical change and the use of advanced technologies. 
In absolute terms, the direct knowledge stock still dominates these indirect knowledge stocks. From 1986 to 1995, the ratio of the direct knowledge stock to the sum of both the domestic and foreign indirect knowledge stocks decreased from 1.3 to 1.0, however. The importance of knowledge spillovers for Dutch manufacturing thus seems to be increasing over time, particularly with regard to spillovers originating from abroad; whereas the direct and indirect domestic knowledge stocks almost doubled in size between 1986 and 1995, the foreign knowledge stock showed a threefold increase. Table 2 reports the relative contribution of each sector to the domestic direct and indirect knowledge stocks, which are calculated as follows:

$$
\frac{C_{j} / \sum_{j} C_{j}}{Y_{j} / \sum_{j} Y_{j}}
$$

and

$$
\frac{I C D_{j} / \sum_{j} I C D_{j}}{Y_{j} / \sum_{j} Y_{j}}
$$

A value larger than 1 in equations [7a] and [7b] indicates a more than average contribution to the direct or indirect knowledge stock. In Table 2 we use the OECD division (OECD, 1998) of sectors from high-technology sectors to low-technology sectors. ${ }^{13}$ The table shows that this value exceeds 1 for the following seven sectors: Pharmaceuticals; Office and computing equipment; Radio, TV and communication equipment; Aerospace; Other chemicals; Electrical machinery; and Automobiles. The former four sectors are included in the high-technology group and the latter three are included in the medium-high-technology category. The final column of Table 2 reports for each sector the relative contribution of the indirect knowledge stock divided by that of the direct knowledge stock. Moving down the spectrum of technology intensity this value tends increasingly to exceed 1 . These results 
Table 2. Knowledge and relative sector importance

\begin{tabular}{|c|c|c|c|c|c|c|c|}
\hline \multirow[b]{2}{*}{ Sectors } & \multirow[b]{2}{*}{ ISIC code } & \multicolumn{2}{|c|}{$\begin{array}{c}\text { Relative contribution } \\
\text { of direct } \\
\text { knowledge } \\
\text { stock/value added }\end{array}$} & \multicolumn{2}{|c|}{$\begin{array}{c}\text { Relative contribution } \\
\text { of } \\
\text { indirect knowledge } \\
\text { stock/value added }\end{array}$} & \multicolumn{2}{|c|}{ Indirect/direct } \\
\hline & & $1986-90$ & $1991-95$ & $1986-90$ & 1991-95 & $1986-90$ & 1991-95 \\
\hline \multicolumn{8}{|l|}{ High-technology } \\
\hline Pharmaceuticals & 3522 & 3.87 & 4.43 & 3.48 & 4.02 & 0.90 & 0.91 \\
\hline Aerospace & 3845 & 3.34 & 2.25 & 4.14 & 2.68 & 1.24 & 1.19 \\
\hline \multicolumn{8}{|l|}{ Medium-high-technology } \\
\hline Other chemicals & $351+352-3522$ & 1.81 & 1.90 & 1.40 & 1.45 & 0.77 & 0.76 \\
\hline Non-electrical machinery & $382-3825$ & 0.42 & 0.41 & 0.20 & 0.20 & 0.49 & 0.49 \\
\hline Electrical machinery & $383-3832$ & 28.68 & 27.10 & 33.48 & 30.76 & 1.17 & 1.14 \\
\hline Automobiles & 3843 & 1.32 & 1.77 & 1.79 & 2.41 & 1.36 & 1.37 \\
\hline Instruments & 385 & 0.49 & 0.64 & 0.53 & 0.69 & 1.06 & 1.08 \\
\hline Ferrous metals & 371 & 0.42 & 0.52 & 0.47 & 0.61 & 1.13 & 1.16 \\
\hline Non-ferrous metals & 372 & 0.28 & 0.41 & 0.39 & 0.72 & 1.39 & 1.77 \\
\hline Metal products & 381 & 0.14 & 0.16 & 0.16 & 0.19 & 1.16 & 1.13 \\
\hline Shipbuilding & 3841 & 0.16 & 0.13 & 0.21 & 0.20 & 1.37 & 1.50 \\
\hline \multicolumn{8}{|l|}{ Low-technology } \\
\hline Food, beverages and tobacco & 31 & 0.40 & 0.41 & 0.55 & 0.60 & 1.39 & 1.46 \\
\hline Textiles, apparel and leather & 32 & 0.11 & 0.12 & 0.16 & 0.18 & 1.41 & 1.46 \\
\hline Wood products and furniture & 33 & 0.02 & 0.02 & 0.04 & 0.04 & 1.80 & 1.94 \\
\hline Paper, paper products and printing & 34 & 0.03 & 0.03 & 0.05 & 0.05 & 1.48 & 1.56 \\
\hline
\end{tabular}

Note: See the text and Table 1 for details. 
suggest that low- and medium-low-technology sectors contribute relatively more to the country's indirect knowledge stock than to their own direct knowledge stock, emphasizing the role of knowledge spillovers in determining labour productivity. Here, each additional dollar spent on increasing the direct knowledge stock is accompanied by an increase of the indirect knowledge stock of more than $\$ 1 .{ }^{14}$ We use these knowledge indicators in the next section to consider the correlation between the wage structure and several measures of technical change and technology use.

In this section we have shown that knowledge spillovers are likely to be an important determinant in explaining labour productivity. What is of interest in the remainder of this paper is whether knowledge-intensive sectors pay different wages from less knowledge-intensive sectors. This is what we turn to next.

\section{Do knowledge-intensive sectors pay higher wages?}

In this section we examine whether there appears to be a correlation between sectors in manufacturing embodying relatively large amounts of knowledge, either by engaging in $\mathrm{R} \& \mathrm{D}$ processes themselves or by benefiting from research carried out in other sectors and/or countries, and the wages they pay relative to less knowledge-intensive sectors. In doing so wage differentials are defined in two ways: (i) wage differentials between white- an bluecollar workers and (ii) wage differentials between high- and lowskilled workers on the basis of distinguishing between their educational levels. In this manner it is possible to determine whether in some sectors wage differentials can be attributed to job types (white-collar versus blue-collar) or whether wage differentials can be attributed to job levels (high-skilled versus low-skilled jobs).

The labour-market data utilized in this section are drawn from seven surveys conducted by the Organisation for Strategic Labour Market Research (OSA) from 1986 to 1996 among a relatively small number of individuals. For six biannual years 2,325 (1986), 2,279 (1988), 2,352 (1990), 2,399 (1992), 2,531 (1994), and 2,654 (1996) valid observations are available, respectively (the total number of valid observations is 14,540). The analysis here includes only employees, leaving aside self-employed workers because of the highly erratic and unreliable observations of their gross hourly wage income; unemployed people and people not in the labour market are, of course, also excluded since they cannot be attached 
to jobs and sectors. The OSA databases contain many standard labour-market variables, which are often used in the literature and need no further explanation. The only exception is the definition of the five different job levels (elementary, low, medium, high and scientific), which are divided into white-collar and blue-collar jobs (except for elementary jobs). These characteristics were aggregated from over 1,000 four-digit job titles into these nine categories based on a code classification scheme performed by the Dutch Central Bureau of Statistics (CBS), which analyses (comparable to the US Dictionary of Occupational Titles) the type of work done in a particular job.

\subsection{Preliminary estimates}

To start with we have analysed the following standard wage equation:

$$
\ln W_{i}=B+\alpha X_{i}+\varepsilon_{i},
$$

where $\ln W_{i}$ is the $\log$ of the gross hourly wage of individual $i, B$ is a constant term, $X_{i}$ is a vector of personal characteristics including the usual suspects like age and age squared, years of education, female, married and non-Dutch, and $\varepsilon_{i}$ is an error term with the usual assumptions. Table 3 summarizes the main coefficients of this regression analysis.

The results from estimating equation [8] are standard to the literature. In the first column we did not include sector and occupational dummies. The results reported in the second column do include occupational dummies and the results displayed in the third column also include sector dummies. The results from this exercise can be summarized as follows. First, age (as a proxy for work experience) has a positive effect on wages, which is subject to decreasing returns to scale (age squared is negative). Secondly, an additional year of education yields between 3 and 5 percent higher wages. Thirdly, women seem to earn less but people who are nonDutch do not seem to receive lower wages.

When we include dummies for white-collar workers into the regression results reported in the first column of Table 3, it turns out that white-collar workers receive a wage premium of 15.2 percent relative to blue-collar workers. Controlling for sector of industry does not change this coefficient to any large extent (15.3 percent). Including the distinction between high-skilled ( $>15$ years 
Table 3. Estimation results of a simple wage equation (dependent variable $\ln$ (gross hourly wage))

\begin{tabular}{lcrr}
\hline & $\mathbf{1}$ & $\mathbf{2}$ & \multicolumn{1}{c}{$\mathbf{3}$} \\
\hline Constant & $0.521(0.049)^{*}$ & $0.467(0.052)^{*}$ & $0.533(0.054)^{*}$ \\
Age & $0.065(0.002)^{*}$ & $0.055(0.001)^{*}$ & $0.055(0.001)^{*}$ \\
Age squared & $-0.001(0.000)^{*}$ & $-0.001(0.000)^{*}$ & $-0.001(0.000)^{*}$ \\
Education & $0.047(0.001)^{*}$ & $0.028(0.002)^{*}$ & $0.027(0.002)^{*}$ \\
Female & $-0.161(0.008)^{*}$ & $-0.123(0.008)^{*}$ & $-0.111(0.009)^{*}$ \\
Non-Dutch & $0.001(0.016)$ & $-0.000(0.000)$ & $-0.002(0.018)$ \\
Sector dummies & No & No & Yes \\
Occupational dummies & No & Yes & Yes \\
$R^{2}$ adj. & 0.391 & 0.434 & 0.441 \\
\hline
\end{tabular}

Notes: The data are taken from the biannual OSA databases, 1986-96. Standard errors are shown in parentheses.

*Significant at the 5 percent level.

The coefficient on education should be interpreted as the wage premium for an additional year of education. All regressions include unreported year dummies. Sector dummies are defined as the sector of employment of individual $i$ (see Table 2) and occupational dummies refer to the nine different occupational levels we distinguish.

of education) and low-skilled ( $<15$ years of education) workers leads to a wage differential of 14.8 percent when using the specification as reported in column (1) of Table 3 . When we control for sector of industry, the coefficient does not change significantly (15.0 percent). Including the dummy white-collar $\times$ high-skilled leads to a wage premium of 14.9 percent in the first specification and to a rather similar wage premium when controlling for sector of industry (15.0 percent). Finally, these coefficients do not seem to have changed over time because when we analyse the annual coefficients separately, they cannot be statistically distinguished from one another.

To see whether a correlation exists between knowledge intensity and the level of wages in The Netherlands in the period 1986-95, we use the distinction between the degrees of technology advancement as defined by the OECD (OECD, 1998) and reported in Table 2. To analyse this correlation we estimate the following equation:

$$
\ln W_{i}=B+\alpha X_{i}+\beta T_{i}+\varepsilon_{i}
$$

where $T_{i}$ is a variable for technological advancement. The four levels of technological advancement used in the regression are 
high-technology, medium-high-technology, medium-low-technology and low-technology sectors, as distinguished in Table 2. The results of the regression analysis of equation [9] are reported in Table 4.

The results can be summarized as follows. In the results reported in column (1) we again only included personal characteristics into the estimation along with $T_{i}$. The results indicate that, relative to the low-technology sector, the higher the level of technological advancement the higher the overall level of wages. When we include the occupational dummies, distinguishing between job levels, the results reported in column (2) of Table 4 do not change to a large extent. This seems to indicate that similar occupations (in terms of occupational levels) receive different wages in different sectors. ${ }^{15}$

Distinguishing between white-collar and blue-collar workers leads to higher (and significant) coefficients for the technological advancement variable. These regression results, reported in column

Table 4. Wages, job level and type, and technological advancement (dependent variable ln (gross hourly wage))

\begin{tabular}{lcccc}
\hline & $\mathbf{1}$ & $\mathbf{2}$ & $\mathbf{3}$ & $\mathbf{4}$ \\
\hline Constant & $0.510(0.089)^{*}$ & $0.542(0.088)^{*}$ & $0.505(0.093)^{*}$ & $0.558(0.053)^{*}$ \\
Age & $0.062(0.004)^{*}$ & $0.059(0.006)^{*}$ & $0.058(0.008)^{*}$ & $0.055(0.009)^{*}$ \\
Age squared & $-0.000(0.000)^{*}$ & $-0.000(0.000)^{*}$ & $-0.000(0.000)^{*}$ & $-0.000(0.000)^{*}$ \\
Education & $0.044(0.002)^{*}$ & $0.044(0.001)^{*}$ & $0.042(0.024)^{*}$ & $0.033(0.024)^{*}$ \\
Female & $-0.120(0.010)^{*}$ & $-0.110(0.008)^{*}$ & $-0.141(0.013)^{*}$ & $-0.132(0.015)^{*}$ \\
Non-Dutch & $0.000(0.015)$ & $-0.000(0.015)$ & $-0.002(0.013)$ & $-0.002(0.016)$ \\
Sectors $\left(T_{i}\right)$ & & & & \\
$\quad$ Medium-low & $0.016(0.008)^{*}$ & $0.018(0.008)^{*}$ & $0.033(0.006)^{*}$ & $0.068(0.006)^{*}$ \\
$\quad$ Medium-high & $0.020(0.009)^{*}$ & $0.019(0.009)^{*}$ & $0.071(0.006)^{*}$ & $0.089(0.006)^{*}$ \\
\multicolumn{1}{l}{ High } & $0.025(0.011)^{*}$ & $0.029(0.014)^{*}$ & $0.086(0.005)^{*}$ & $0.093(0.009)^{*}$ \\
\hline Sector dummies & No & Yes & Yes & Yes \\
$R^{2}$ adj. & 0.399 & 0.416 & 0.445 & 0.441 \\
\hline
\end{tabular}

Notes: The data are taken from the biannual OSA databases, 1986-96. Standard errors are shown in parentheses.

* Significant at the 5 percent level.

The coefficient on education should be interpreted as the wage premium for an additional year of education. All regressions include unreported year dummies. Occupational dummies refer to the nine different occupational levels we distinguish. The technological advancement of a sector is determined using the OECD classification as shown in Table 2. 
(3) of Table 4, suggest that white-collar workers receive significantly higher wages than their blue-collar colleagues. In addition, when distinguishing between high-skilled and low-skilled workers, we observe from column (4) of Table 4, that high-skilled workers receive significantly higher wages in higher-technology sectors relative to the lower-technology sectors. Hence, it seems plausible to assume a positive correlation between technological advancement and the level of wages in a sector. This positive correlation between wages and technological advancement is consistent with the observations for the USA by Doms et al. (1997) and Autor et al. (1998). The former finds a positive correlation between R\&D intensity and the use of modern technologies and the overall level of wages, and the latter finds similar results with regard to computer use. Results obtained by Chennells and Van Reenen (1997) for the UK and Entorf and Kramarz (1997) and Entorf et al. (1999) for France report similar correlations between a sector's wage level and its level of technological advancement.

\subsection{Industry wage differentials and knowledge intensity}

While these regression results are interesting, the analysis presented in Section 2 suggests that not only the development of technology, reflected by, for example, R\&D intensity, but also the use of advanced technology might be of importance in explaining the technological advancement of a sector. In this section we take into account the results of this spillover analysis when evaluating the wage structure of the Dutch manufacturing sector. To do so we add for each year four estimations to the analysis (see also Table 2). First, we classify sectors into the four classes of technological advancement with respect to the relative contribution of their direct knowledge stock. Secondly, we use the relative contribution of their indirect knowledge stock. Thirdly, we apply the ratio between these two knowledge stocks. Finally, we compute the total knowledge intensity as the sum of the direct knowledge stock, the domestic indirect knowledge stock, and the foreign knowledge stock divided by value added, and relate this to the wages. These characterizations of technology are computed for the relevant years for which we have labour-market data (each biannual year from 1986 to 1996), except for 1996. Because knowledge data for 1996 are absent we use the knowledge variables of 1995 . 
To rank the scores on each of the four measures of knowledge intensity of the different manufacturing sectors we have divided the data into four quartiles of the knowledge distribution of the different variables we use. This is similar to the OECD's classification shown in Table 2.

The results of these four estimations are presented in Table 5. We include only the full estimations, leaving the different specifications unreported because they do not yield additional insight. In the first column of Table 5 the results from estimating a wage equation with the relative contribution of the direct knowledge stock are reported. Not surprisingly, these results suggest similar wage premiums as the results reported in the first two columns of Table 4. Including dummies for white-collar and high-skilled workers leads to similar results, as reported in the last two columns of Table 4. These coefficients are reported in the last two rows of Table 5 and reflect the inclusion of an additional

Table 5. Wages and knowledge spillovers (dependent variable ln (gross hourly wage))

\begin{tabular}{lcccc}
\hline & Direct & Indirect & Indirect/direct & \multicolumn{1}{c}{ Overall } \\
\hline Constant & $0.500(0.087)^{*}$ & $0.510(0.078)^{*}$ & $0.505(0.097)^{*}$ & $0.555(0.050)^{*}$ \\
Age & $0.063(0.003)^{*}$ & $0.060(0.007)^{*}$ & $0.062(0.006)^{*}$ & $0.062(0.009)^{*}$ \\
Age squared & $-0.000(0.000)^{*}$ & $-0.001(0.000)^{*}$ & $-0.001(0.000)^{*}$ & $-0.001(0.000)^{*}$ \\
Education & $0.047(0.001)^{*}$ & $0.043(0.002)^{*}$ & $0.045(0.001)^{*}$ & $0.046(0.004)^{*}$ \\
Female & $-0.140(0.009)^{*}$ & $-0.119(0.010)^{*}$ & $-0.127(0.010)^{*}$ & $-0.146(0.020)^{*}$ \\
Non-Dutch & $0.001(0.015)$ & $-0.000(0.010)$ & $-0.000(0.013)$ & $0.001(0.016)$ \\
Sectors $\left(T_{i}\right)$ & & & & \\
$\quad$ Medium-low & $0.015(0.007) *$ & $0.013(0.007)$ & $0.008(0.007)$ & $0.013(0.007)$ \\
$\quad$ Medium-high & $0.020(0.008)^{*}$ & $0.019(0.010)$ & $0.017(0.010)$ & $0.021(0.009)^{*}$ \\
$\quad$ High & $0.027(0.010)^{*}$ & $0.026(0.012)^{*}$ & $0.026(0.013)^{*}$ & $0.028(0.012)^{*}$ \\
High-skilled & $0.150(0.075)^{*}$ & $0.149(0.079)$ & $0.148(0.079)$ & $0.151(0.080)$ \\
White-collar & $0.120(0.059) *$ & $0.119(0.059) *$ & $0.118(0.058)^{*}$ & $0.120(0.059)^{*}$ \\
Sector dummies & Yes & Yes & Yes & Yes \\
$R^{2}$ adj. & 0.411 & 0.392 & 0.402 & 0.441 \\
\hline
\end{tabular}

Notes: The data are taken from the biannual OSA databases, 1986-96. Standard errors are shown in parentheses.

*Significant at the 5 percent level.

The coefficient on education should be interpreted as the wage premium for an additional year of education. All regressions include unreported year dummies. Occupational dummies refer to the nine different occupational levels we distinguish. The technological advancement of a sector is determined differently in each of the four columns. Based on the intensities as shown in Table 2, a ranking is made which uses the four quartiles of the distribution of intensities to determine the four classes of technological advancement. 
dummy for high-skilled (technology advancement $\times$ high-skilled) and white-collar (technology advancement $\times$ white-collar) workers.

The second column of Table 5 reports the regression results of a specification based on a technological advancement division relative to the contribution of the indirect knowledge stock. The labour-market coefficients remain similar, but the coefficients reported for the technological advancement change significantly. Relative to the low-technology sectors (defined as the first quartile of the indirect knowledge stock distribution), mediumlow and medium-high sectors do not pay higher wages. Only the high-technology sectors (fourth quartile of the indirect knowledge stock distribution) pay higher wages than the other sectors. Also interesting to observe is the insignificant coefficient for highskilled workers. This coefficient measures whether high-skilled workers are paid different wages in different sectors, distinguished by their technological advancement. The results presented here suggest no significant wage differentials between high-skilled workers in technologically advanced and other sectors. The white-collar workers still receive significantly higher wages when the contribution to the indirect knowledge stock is higher, reflecting a significant and positive correlation between wages and a sector's technological advancement for white-collar workers.

The results, including the ratio between the contribution to the direct and indirect knowledge stocks presented in the third column of Table 5, suggest similar patterns as reported for the inclusion of the indirect knowledge stock only. Again, only workers in the technologically most advanced sectors obtain higher wages; the same holds for white-collar workers and high-skilled workers, who are not paid differently between sectors.

The final column reports the regression results of including a division of sectors based on their overall knowledge stock. This regression is of central interest because this estimation includes the overall knowledge intensity of a sector. Based on a division into four quartiles we observe again that relative to the technologically least advanced sectors, the medium-low sector does not pay significantly higher wages. The other two sectors do pay higher wages, but the coefficients are much lower than those reported in Table $4 .{ }^{16}$ This indicates that taking into account the overall knowledge intensity of a particular sector leads to a much more moderate relationship between wages and technological advancement. It also suggests that merely using $R \& D$ intensities 
to determine the technological advancement of a sector overestimates the effects of technology on wages to some extent. Apparently, the use of advanced technologies goes along with much more moderate wage differentials than the development of these technologies. This is consistent with the observation that before a technology is being implemented for use it requires recognition of its possibilities and options in order to apply and use it effectively. ${ }^{17}$

Overall, these results suggest that not only should technology developments be taken into account when looking at wage differentials between workers, but that it is equally important to consider spillovers which reflect the use of these developments in any analysis of wage differentials. The positive correlation between wages and technological advancement remains, but to a much lesser extent.

\section{Concluding remarks}

This paper has presented findings suggesting that sectors embodying and creating relatively high levels of knowledge, by performing $R \& D$ and building a sector-specific knowledge stock, pay their workers higher wages. This positive correlation has been observed several times for many OECD countries in past years. ${ }^{18}$ In particular, the analysis reveals findings that (i) the knowledgeintensive sectors seem to pay a higher wage to white-collar workers relative to blue-collar workers than less knowledge-intensive sectors; and (ii) the knowledge-intensive sectors pay a higher wage to high-skilled workers relative to low-skilled workers than less knowledge-intensive sectors.

By analysing explicitly the creation of knowledge we have provided a picture of the underlying mechanisms regarding the technology involved in the production process in Dutch manufacturing. The results suggest that differences exist between sectors with regard to knowledge creation, which seems to lead to a bias in the rewards of both white-collar and high-skilled labour between manufacturing sectors. However, our results also suggest a more careful use of technology variables when analysing the wage structure or labour-market changes resulting from technical change. When taking into account several measures of knowledge spillovers, our results suggest much more moderate and sometimes even insignificant wage differentials. This suggests that measures 
aiming at describing technological developments seem to be positively correlated to wage differentials between workers in different manufacturing sectors, but technology measures aimed at describing the use of advanced technologies seem to go along to a much lesser extent with wage differentials between workers. Hence, focusing only on technology development leads to some overestimation of the wage differentials between workers in different sectors.

\section{Notes}

${ }^{1}$ See, for example, Katz and Murphy (1992), Juhn et al. (1993), Berman et al. (1994), Berman et al. (1998), Machin and Van Reenen (1998) and Alyan (1999). The debate on the wage premium related to particular skills due to new technologies at the individual level has been initiated by Krueger (1993) who disclosed a wage premium on computer use. Yet, the evidence from several studies is not conclusive. Chennells and Van Reenen (1997), Entorf and Kramarz (1997) and Doms et al. (1997) show that workers using computers received a higher wage even before they started using computers; in a critical assessment of Krueger's results, DiNardo and Pischke (1997) observe for Germany that the use of pencils has a similar effect on wages as the use of computers; and Borghans and Ter Weel (2001) show that computer skills are generally not rewarded by employers. Rather, computer use seems to be explained by the fact that high-wage workers get the computer first as a result of cost efficiency.

${ }^{2}$ See, for example, Chennells and Van Reenen (1999) for an overview of more than 100 empirical studies.

${ }^{3}$ See, for example, Machin and Van Reenen (1998). They point towards a possible role for spillovers but do not investigate them structurally.

${ }^{4}$ See, for example, Griliches (1998) for an overview.

${ }^{5}$ This long-run equilibrium model is a useful tool for investigating the extent to which a country's productivity level depends on domestic and foreign R\&D capital stocks. Bernstein and Mohnen (1991) have shown that it is important to account for temporary deviations from long-run equilibrium growth paths in measuring productivity growth, because simply assuming that producers are always employing their long-run equilibrium capital stock can lead to biases in measured productivity growth. Bernstein and Mohnen (1998) account for these deviations from long-run equilibrium by using adjustment costs. Their results are in line with other studies relating to domestic R\&D spillovers - see Griliches (1992), as well as the social rates obtained by Coe and Helpman (1995) in a multicountry context, and Coe et al. (1997) in a North-South model. In his analysis, Griliches (1992) defines rent spillovers generated by international trade, on the one hand, and knowledge spillovers generated by blueprints like patent information, scientific literature and imitation, on the other. These latter knowledge spillovers are particularly relevant to the analysis we want to carry out in this paper.

${ }^{6}$ Our analysis includes the following 22 sectors (ISIC code in parentheses): Food, beverages and tobacco (31); Textiles, apparel and leather (32); Wood products and 
furniture (33); Paper, paper products and printing (34); Pharmaceuticals (3522), Other chemicals $(351+352-3522)$; Refined oil and related products $(353+354)$; Rubber and plastic products $(355+356)$; Glass, stone and clay (36); Ferrous metals (371); Non-ferrous metals (372); Metal products (381); Non-electrical machinery (382-3825); Office and computing equipment (3825); Radio, TV and communication equipment (3832); Electrical machinery (383-3832); Shipbuilding (3841); Automobiles (3843); Aerospace (3845); Other transport equipment (384-38413843-3845); Instruments (385); and Other manufacturing (39).

${ }^{7}$ The initial capital and knowledge stocks are defined in line with definitions suggested in Griliches (1980) in the following manner: $K_{0}=\left(I_{K, 1}\right) /(\varphi+0.05)$ and $C_{0}=\left(I_{C, 1}\right) /(\chi+0.05)$. We use data information from 1973-85 to construct these stocks in order not to lose information for the period 1986-95.

${ }^{8}$ The other two matrices of Verspagen (1997) are (i) aimed at measuring rent spillovers, as in Griliches (1979); and (ii) measuring spillovers on the basis of patent citation information using data from the US Patent Office, as in Putnam and Evenson (1994).

${ }^{9}$ Note that the diagonal of the technology flow matrix with respect to the calculation of the domestic knowledge stock is set to zero to exclude the problem of multicollinearity, i.e. $\omega_{j j}=0$.

${ }^{10}$ To which an error term is added.

${ }^{11}$ This result is consistent with the results reported by Coe and Helpman (1995) and Verspagen (1997).

${ }^{12}$ Verspagen (1997) observes similar coefficients for other OECD countries.

${ }^{13}$ This OECD classification is based on a division of sectors based on the quartiles of the R\&D intensity distribution. In that way four technology classes can be constructed ranging from high technology to low technology.

${ }^{14}$ The exceptionally high values in Table 2 for the Electrical machinery sector is due to Philips. All expenditures on R\&D have been computed to apply to this sector, while the production of Philips takes place in many sectors.

${ }^{15}$ It might also be interesting to see whether this effect is changing over time. When we attach year dummies to the technological advancement variables we do not observe any trend. The coefficient remains rather stable over time, in that we cannot discriminate statistically between the coefficients for different years.

${ }^{16}$ Again, if we run the regression for each biannual year between 1986 and 1996 separately, the results do not change. Hence, the reported patterns seem to be rather consistent over time.

${ }^{17}$ Borghans and Ter Weel (2001) present such evidence for the introduction and adoption of computers at the workplace. They find that the introduction of computerized equipment at work is based on the specific tasks a worker has to carry out and his/her wages.

${ }^{18}$ At a more macro-economic level Berman and Machin (2000) also seem to obtain a positive correlation between technical change and wages in developing countries.

\section{References}

Acemoglu D. (1998) 'Why Do New Technologies Complement Skills? Directed Technical Change and Wage Inequality', Quarterly Journal of Economics 113: $1055-1089$. 
Alyan N. (1999) 'The Role of Capital Intensity and Technology Usage in Upgrading Skills in the US Labor Market', Technological Forecasting and Social Change 61: 59-74.

Autor D. H., Katz L. F. and Krueger A. B. (1998) 'Computing Inequality: Have Computers Changed the Labor Market?', Quarterly Journal of Economics 113: $1169-1213$.

Berman E., Bound J. and Griliches Z. (1994) 'Changes in the Demand for Skilled Labor within US Manufacturing: Evidence from the Annual Survey of Manufactures', Quarterly Journal of Economics 109: 367-397.

Berman E., Bound J. and Machin S. (1998) 'Implications of Skill-biased Technological Change: International Evidence', Quarterly Journal of Economics 113: 1245-1279.

Berman E. and Machin S. (2000) 'Skill-biased Technology Transfers: Evidence of Factor-biased Technological Change in Developing Countries', Mimeo, Boston University.

Bernstein J. I. and Mohnen P. (1991) 'Price-Cost Margins, Exports and Productivity Growth: With an Application to Canadian Industries', Canadian Journal of Economics 24: 638-659.

Bernstein J. I. and Mohnen P. (1998) 'International R\&D Spillovers between US and Japanese R\&D Intensive Sectors', Journal of International Economics 44: $315-338$.

Borghans L. and Ter Weel B. (2001) 'Computers, Skills and Wages', Mimeo, Maastricht University.

Chennells L. and Van Reenen J. (1997) 'Technical Change and Earnings in British Establishments', Economica 64: 587-604.

Chennells L. and Van Reenen J. (1999) 'Has Technology Hurt Less Skilled Workers? An Econometric Survey of the Effects of Technical Change and the Structure of Pay and Jobs', Mimeo, University College London.

Coe D. T. and Helpman E. (1995) 'International R\&D Spillovers', European Economic Review 39: 859-887.

Coe D. T., Helpman E. and Hoffmaister A. (1997) 'North-South R\&D Spillovers', Economic Journal 107: 134-149.

Denny M. and Fuss M. (1983) 'The Effects of Factor Prices and Technological Change on the Occupational Demand for Labour: Evidence from Canadian Telecommunications', Journal of Human Resources 19: 161-176.

DiNardo J. E. and Pischke J.-S. (1997) 'The Returns to Computer Use Revisited: Have Pencils Changed the Wage Structure Too?', Quarterly Journal of Economics 112: 291-303.

Doms M., Dunne T. and Troske K. R. (1997) 'Workers, Wages and Technology', Quarterly Journal of Economics 112: 253-290.

Entorf H. and Kramarz F. (1997) 'Does Unmeasured Ability Explain the Higher Wages of New Technology Workers?', European Economic Review 41: 1489-1509.

Entorf H., Gollac M. and Kramarz F. (1999) 'New Technologies, Wages and Worker Selection', Journal of Labor Economics 17: 464-491.

Goldin C. and Katz L. F. (1998) 'The Origins of Technology-Skill Complementarity', Quarterly Journal of Economics 113: 693-732.

Griliches Z. (1969) 'Capital-Skill Complementarity', Review of Economics and Statistics 51: 465-468.

Griliches Z. (1979) 'Issues in Assessing the Contribution of Research and 
Development to Productivity Growth', Bell Journal of Economics 10: 92-116.

Griliches Z. (1980) 'R\&D and Productivity Slowdown', American Economic Review 70: 343-348.

Griliches Z. (1992) 'In Search for R\&D Spillovers', Scandinavian Journal of Economics 94: 29-47.

Griliches Z. (1998) $R \& D$ and Productivity: The Econometric Evidence, Chicago: Chicago University Press.

Juhn C., Murphy K. M. and Pierce B. (1993) 'Wage Inequality and the Rise in Returns to Skill', Journal of Political Economy 101: 410-442.

Katz L. F. and Murphy K. M. (1992) 'Changes in Relative Wages, 1963-1987: Supply and Demand Factors', Quarterly Journal of Economics 107: 35-78.

Kortum S. and Putnam J. (1997) 'Assigning Patents to Industries: Tests of the Yale Technology Concordance', Economic Systems Research 9: 161-175.

Krueger A. B. (1993) 'How Computers Have Changed the Wage Structure: Evidence from Micro Data 1984-1989', Quarterly Journal of Economics 108: $33-60$.

Machin S. and Van Reenen J. (1998) 'Technology and Changes in Skill Structure: Evidence from Seven OECD Countries', Quarterly Journal of Economics 113: $1215-1244$.

OECD (1998) Science, Technology and Industry Outlook 1998, Paris: OECD.

Putnam J. and Evenson R. (1994) 'Inter-sectoral Technology Flows: Estimates from a Patent Concordance with an Application to Italy', Mimeo, Yale University.

Soete L. and Ter Weel B. (1999) 'Innovation, Knowledge Creation and Technology Policy: The Case of the Netherlands', De Economist 147: 293-313.

Verspagen B. (1997) 'Estimating International Technology Spillovers Using Technology Flow Matrices', Weltwirtschaftliches Archiv 133: 226-248. 